Jurnal Fokus Manajemen Bisnis
Vol.11, No.1, Maret 2021, pp. 95-110
https://doi.org/10.12928//fokus.v11i1.3735
http://journal2.uad.ac.id/index.php/fokus
$\begin{aligned} & \text { Universitas } \\ & \text { Ahmad Dahlan }\end{aligned}$

\title{
PENGARUH KETIDAKPASTIAN KEBIJAKAN EKONOMI AMERIKA SERIKAT, TIONGKOK, DAN JEPANG TERHADAP JAKARTA ISLAMIC INDEX
}

\author{
Maulidia Royhana ${ }^{1}$, Titi Dewi Warninda ${ }^{2, *}$ \\ Universitas Islam Negeri Syarif Hidayatullah Jakarta \\ titi.dewi@uinjkt.ac.id \\ *Titi Dewi Wardinda
}

ABSTRACT

Article history

Received 2021-02-23

Revised 2021-02-26

Accepted

Keywords

United State EPU

Tiongkok EPU

Japan EPU

Jakarta Islamic Index

Error Correction Model
This research aims to analyze the influence of United State Economic Policy Uncertainty, Tiongkok Economic Policy Uncertainty, and Japan Economic Policy Uncertainty on the Jakarta Islamic Index. This study used time-series data from January 2001 to December 2019 and Error Correction Model to analyze the shortterm and long-term effects of United State, Tiongkok, and Japan Economic Policy Uncertainty on the Jakarta Islamic Index. The results of this research show that United State EPU and Tiongkok EPU have no short-term and long-term effect on Jakarta Islamic Index. Meanwhile, in the short-term, Japan EPU has a significant influence on the Jakarta Islamic Index but has no long-term influence.

This is an open-access article under the CC-BY-SA license.

\section{Pendahuluan}

Indonesia merupakan negara dengan jumlah penduduk muslim terbesar di dunia. Menurut data Badan Pusat Statistik (BPS) tahun 2018, jumlah penduduk Indonesia yang beragama Islam (muslim) sebanyak 225,29 juta jiwa atau $85 \%$ dari total jumlah penduduk. Data tersebut menjadikan Indonesia sebagai pangsa pasar yang besar untuk turut aktif dalam industri keuangan syariah dengan tujuan agar para investor muslim dapat ikut berkontribusi dalam pembangunan negara melalui pasar modal yang sesuai dengan syariat Islam (Oktaviani, 2017).

\section{Perkembangan Kapitalisasi Pasar JII}

$$
\begin{array}{r}
4,000,000.00 \\
3,000,000.00 \\
2,000,000.00 \\
1,000,000.00 \\
0.00
\end{array}
$$

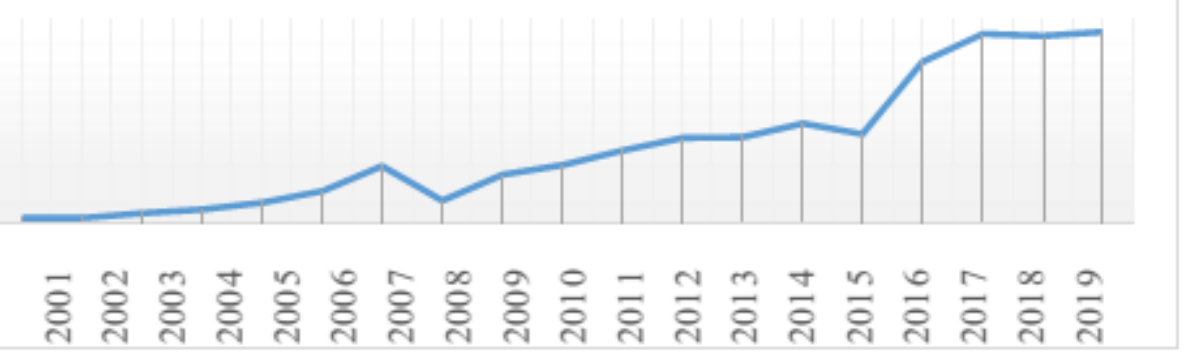

Sumber: www.ojk.go.id (2020)

\section{Gambar 1. Kapitalisasi Indeks Saham Syariah}


Gambar 1 menunjukkan bahwa perkembangan kapitalisasi Jakarta Islamic Index (JII) yang merupakan indeks saham syariah di pasar modal Indonesia mengalami tren naik dari awal periode hingga akhir periode. Namun pada tahun 2008 nilai kapitalisasi indeks saham syariah JII mengalami penurunan yang tajam.

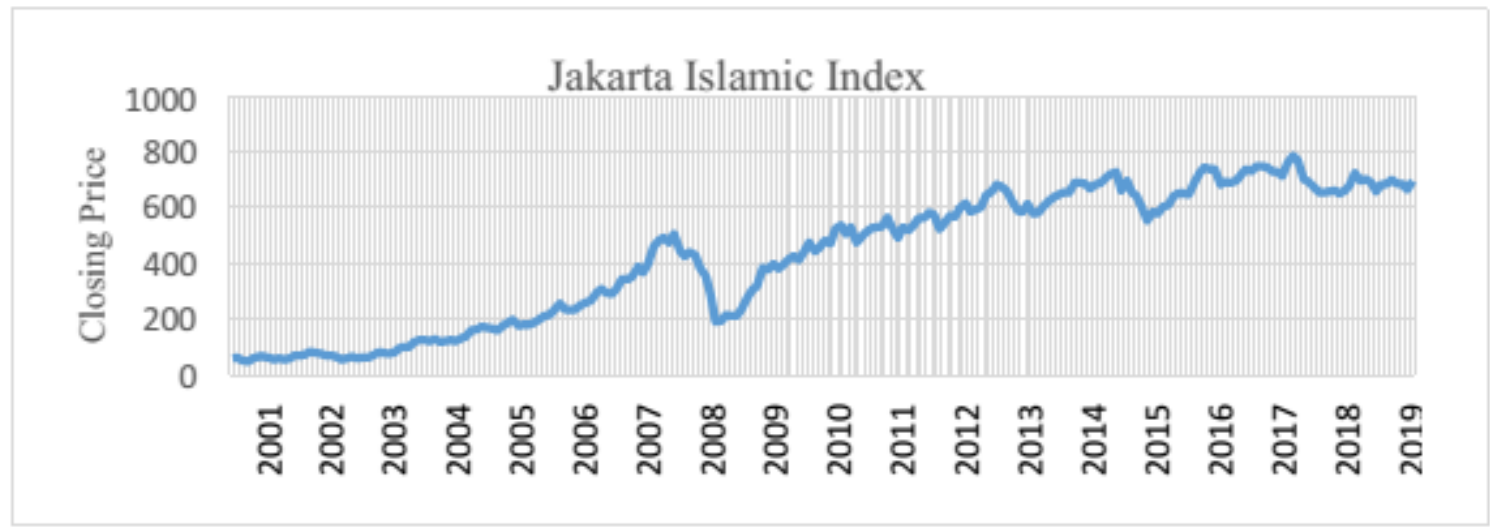

Sumber: www.idx.co.id (2020)

Gambar 2. Perkembangan Indeks Saham Syariah

Gambar 2 menunjukkan sebelum terjadinya krisis keuangan global pada September 2008, kinerja JII berada di tingkat puncak. Namun, JII menurun secara tajam sebanyak 300 poin dari tahun 2007 sampai 2008, yang terjadi karena adanya krisis keuangan global (Sakti dan Harun, 2013). Setelah terjadinya krisis subprime mortgage, perkembangan indeks saham syariah JII berangsur mengalami kenaikan kembali dan berfluktuasi hingga tahun 2019 .

Fluktuasi yang terjadi pada JII menunjukkan bahwa pasar modal syariah dapat terpengaruh oleh situasi perekonomian dunia. Perkembangan ekonomi dapat menimbulkan ketidakpastian, baik secara langsung dan melalui dampaknya terhadap pembuatan kebijakan. Dalam hal ini, krisis keuangan dan kejatuhan ekonomi mendorong peningkatan tajam dalam ketidakpastian kebijakan yang tinggi berkontribusi pada tingkat keparahan krisis dan kelemahan dari pemulihan berikutnya (Davis, 2019).

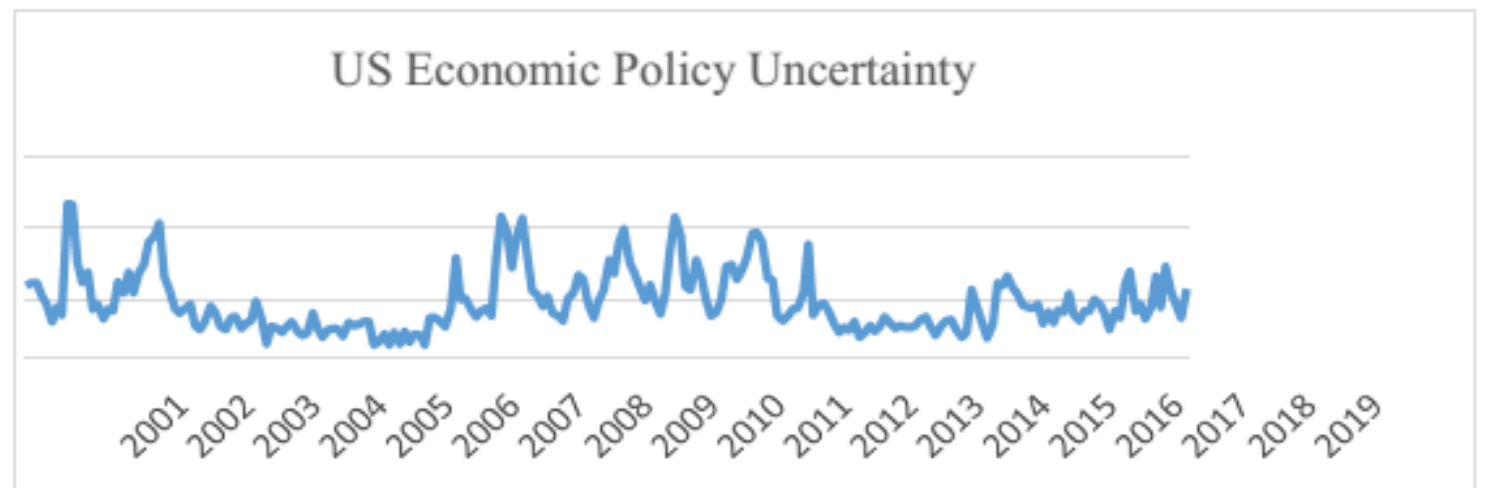

Sumber: www.policyuncertainty.com (2020)

Gambar 3. Perkembangan United State Economic Policy Uncertainty

Gambar 3 adalah grafik indeks United State Economic Policy Uncertainty (US EPU) yang merupakan indeks yang mewakili ketidakpastian yang terjadi di negara Amerika Serikat berdasarkan jumlah artikel di surat kabar. Indeks ini mengalami fluktuasi meningkat tajam saat krisis keuangan global tahun 2008-2009, pertempuran kebijakan fiskal 2011 hingga 2013, reaksi terhadap referendum Brexit Juni 2016, kemenangan pemilu Donald Trump pada 
November 2016, dan peningkatan ketegangan kebijakan perdagangan pada tahun 2018 dan 2019 (Davis, 2019).

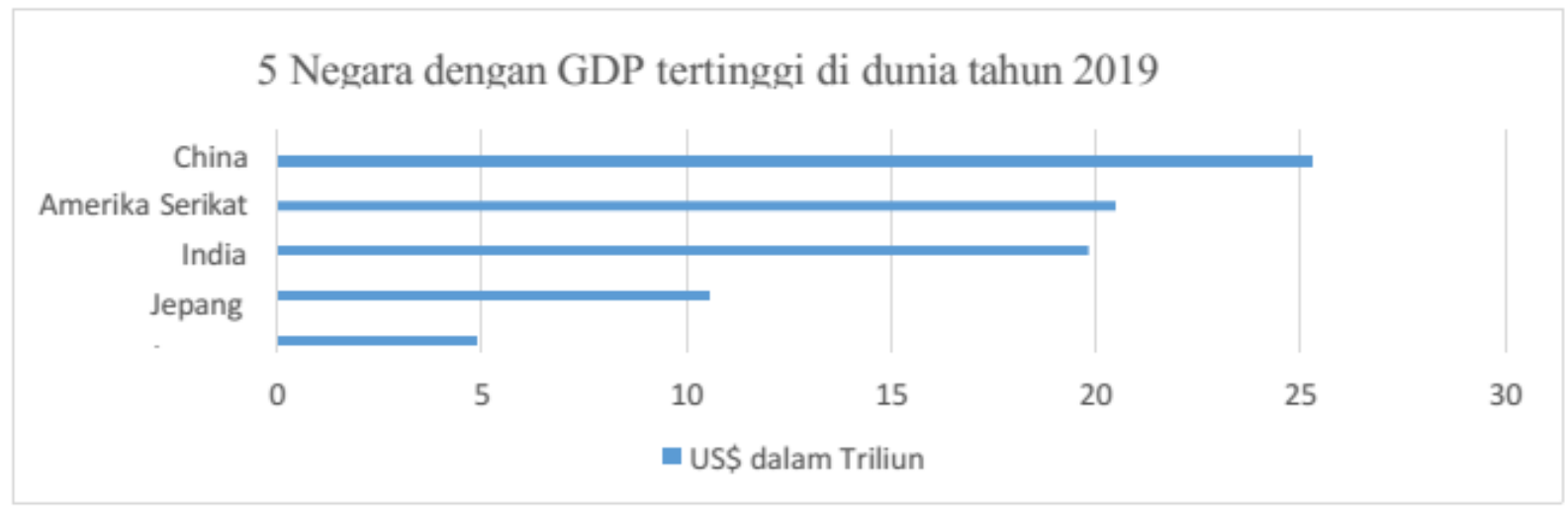

Sumber: www.imf.org (2020)

\section{Gambar 4. GDP Tertinggi di Dunia Tahun 2019}

Gambar 4 menunjukkan pada tahun 2019 Amerika Serikat dan Tiongkok menduduki posisi teratas GDP terbesar di dunia. Amerika Serikat dan Tiongkok adalah penguasa ekonomi terbesar di dunia, yang sangat penting bagi perekonomian dunia. Secara alami, ketidakpastian ekonomi pada negara penguasa ekonomi dunia tidak hanya berpengaruh pada pasarnya sendiri, tetapi juga berdampak pada pasar internasional (Mei et al.,2018).

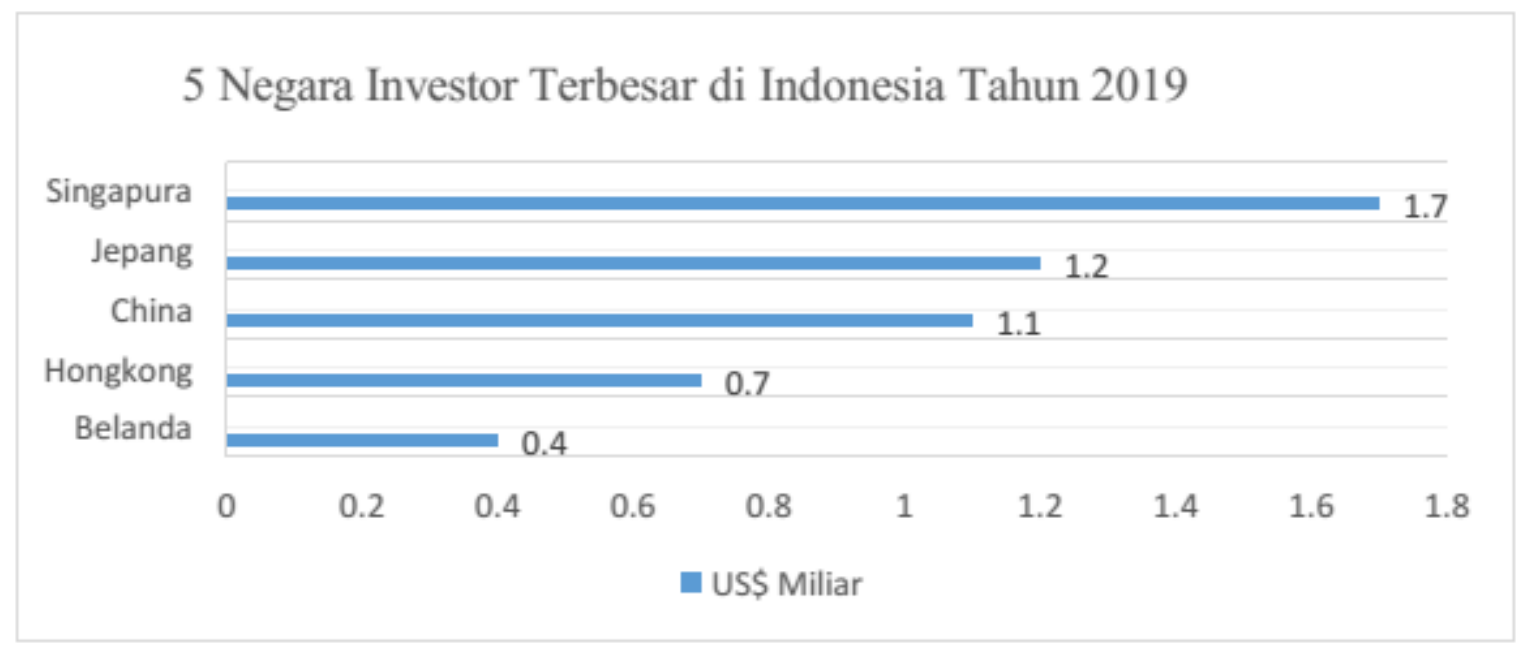

Sumber: www.bkpm.go.id (2020)

\section{Gambar 5. Daftar 5 Negara Investor Terbesar di Indonesia Tahun 2019}

Gambar 5 menunjukkan bahwa negara Jepang menduduki urutan negara tertinggi kedua sebagai investor terbesar di Indonesia dengan nilai investasi mencapai US\$1,7 miliar. Negara Tiongkok menduduki urutan ketiga sebagai investor terbesar dengan nilai investasi mencapai US\$ 4,95 miliar.

Berdasarkan data-data yang tersedia, negara Amerika Serikat, Tiongkok, dan Jepang merupakan negara-negara penting yang dapat memberikan pengaruh besar terhadap Indonesia. Ketidakpastian kebijakan ekonomi pada negara-negara tersebut dapat berpengaruh terhadap Indonesia, terutama terhadap pasar modal Indonesia sebagai salah satu indikator ekonomi. Indonesia merupakan negara dengan penduduk muslim terbesar di dunia, sehingga diperlukan 
penelitian mengenai pengaruh ketidakpastian kebijakan ekonomi Amerika Serikat, Tiongkok, dan Jepang terhadap JII yang merupakan indeks saham syariah di pasar modal Indonesia.

\section{Review Literatur dan Hipotesis}

\subsection{Landasan Teori}

\subsubsection{Pasar Modal Syariah}

Pasar modal (suq maliyah) yaitu kegiatan yang bersangkutan dengan penawaran umum dan perdagangan efek, perusahaan publik yang berkaitan dengan efek yang diterbitkannya serta lembaga dan profesi yang berkaitan dengan efek (Anshari, 2008). Pasar modal syariah adalah pasar modal yang menerapkan prinsip-prinsip syariah dalam kegiatan transaksi ekonomi dan terbebas dari hal-hal yang dilarang oleh ajaran Islam, seperti riba, perjudian, spekulasi, dan lain-lain (Suryomurti, 2011). Selanjutnya Rodoni dan Hamid (2008) menyatakan bahwa pasar modal syariah adalah kegiatan yang berhubungan dengan perdagangan efek syariah perusahaan publik yang berkaitan dengan efek yang diterbitkannya serta lembaga profesi yang berkaitan dengannya, dimana semua produk dan mekanisme operasionalnya tidak bertentangan dengan syariat Islam.

Soemitra (2015) menyatakan bahwa pasar modal syariah adalah pasar modal yang seluruh mekanisme kegiatannya terutama mengenai emiten, jenis efek yang diperdagangkan, dan mekanisme perdagangannya telah sesuai dengan prinsip-prinsip syariah. Pasar modal syariah ini dikembangkan dalam rangka memenuhi kebutuhan umat Islam di Indonesia yang melakukan investasi di pasar modal sesuai dengan prinsip syariah. Sistem mekanisme pasar modal konvensional yang mengandung riba, maysir dan gharar selama ini telah menimbulkan keraguan di kalangan umat Islam karena hal tersebut yang menjadikan pasar modal tidak sesuai dengan syariat Islam (Faniyah, 2017).

\subsubsection{Jakarta Islamic Index (JII)}

Perkembangan pasar modal syariah di Indonesia dimulai dengan diterbitkannya Reksadana Syariah oleh PT. Danareksa Investment Management pada 3 Juli 1997. Kemudian Bursa Efek Indonesia bekerja sama dengan PT. Danareksa Investment Management meluncurkan JII pada tanggal 3 Juli 2000 yang bertujuan untuk memandu investor yang ingin menginvestasikan dananya secara syariah (Umam, 2013). Konstituen JII hanya terdiri dari 30 saham syariah terliquid yang tercatat di Bursa Efek Indonesia. Tujuan JII yang melibatkan 30 saham terpilih yaitu sebagai tolak ukur (benchmark) untuk mengukur kinerja investasi pada saham yang berbasis syariah dan meningkatkan kepercayaan para investor untuk mengembangkan investasi dalam ekuiti syariah atau untuk memberikan kesempatan kepada investor yang ingin melakukan investasi sesuai dengan prinsip-prinsip syariah (Beik, 2014).

Rodoni (2009) menyatakan bahwa JII merupakan indeks terakhir yang dikembangkan oleh Bursa Efek Jakarta (BEJ) yang bekerjasama dengan PT. Danareksa Investment Management untuk merespons kebutuhan informasi yang berkaitan dengan investasi syariah. JII merupakan subset dari Indeks Harga Saham Gabungan (IHSG) yang diluncurkan pada tanggal 3 Juli 2000 dan menggunakan tahun 1 Januari 1995 sebagai database dengan nilai 100 . JII melakukan penyaringan terhadap saham yang listing. Pedoman dalam penyaringannya adalah rujukan dari fatwa syariah yang diterbitkan oleh Dewan Syariah Nasional (DSN). Dengan demikian, sesuai dengan diterbitkannya fatwa ini, BEJ memilih dan memilah emiten yang unit usahanya sesuai dengan syariah. 


\subsubsection{Economic Policy Uncertainty (EPU)}

Ketidakpastian kebijakan ekonomi adalah sebuah perubahan kebijakan ekonomi yang menentukan aturan untuk pelaku ekonomi. Pendekatan ini untuk mengukur ketidakpastian kebijakan menimbulkan potensi kekhawatiran yang terkait dengan keandalan koran, akurasi, bias, dan konsistensi. Untuk mengatasi masalah ini, indeks EPU melakukan beberapa cara. Pertama, menunjukkan hubungan yang kuat antara ukuran ketidakpastian kebijakan ekonomi dan langkah-langkah lain ketidakpastian ekonomi, misalnya, volatilitas pasar modal. Kedua, menunjukkan hubungan yang kuat antara indeks dan langkah-langkah lain ketidakpastian kebijakan, misalnya, frekuensi yang Federal Reserve System Beige Books menyebutkan langkah-langkah lain ketidakpastian kebijakan. Ketiga, menemukan gerakan sangat mirip dalam indeks EPU berdasarkan standar surat kabar, menunjukkan bahwa kemiringan politik tidak serius terhadap fakta indeks EPU secara keseluruhan (Baker et al.,2016).

\subsection{Hipotesis}

2.2.1. Pengaruh Negatif Ketidakpastian Kebijakan Ekonomi Amerika Serikat terhadap Jakarta Islamic Index

Amerika Serikat (AS) adalah ekonomi terbesar di dunia, yang sangat penting bagi perekonomian dunia. Secara alami, ketidakpastian AS mungkin tidak hanya berpengaruh pada pasarnya sendiri, tetapi juga berdampak pada pasar internasional untuk menyelidiki peran ketidakpastian kebijakan (Mei et al.,2018). Peningkatan integrasi perdagangan dan keuangan telah meningkatkan kerentanan negara maju dan berkembang terhadap guncangan eksternal. Terutama guncangan yang menghantam ekonomi AS memiliki efek di seluruh dunia. Ekonomi pasar berkembang lebih rentan terhadap guncangan yang memukul ekonomi AS sebagai salah satu ekonomi terkemuka dunia yang merupakan lebih dari seperempat dari pendapatan global (Gilal, 2019). Ketidakpastian kebijakan ekonomi AS dan global memiliki pengaruh jangka panjang yang signifikan dan negatif terhadap harga saham di Bahrain dan Kuwait (Alqahtani dan Martinez, 2020).

$\mathrm{H}_{1}$ : Ketidakpastian Kebijakan Ekonomi Amerika Serikat Berpengaruh Negatif terhadap Jakarta Islamic Index

\subsubsection{Pengaruh Negatif Ketidakpastian Kebijakan Ekonomi Tiongkok terhadap Jakarta Islamic Index}

Globalisasi ekonomi yang terjadi secara empiris memeriksa guncangan heterogen dari ketidakpastian kebijakan ekonomi global dan nasional ke indeks kondisi keuangan Tiongkok. Tentu saja, sumber faktor yang beragam akan memiliki dampak yang berbeda pada pasar keuangan (Li dan Zhong, 2020). Hasil penelitian Ariputra (2017) mengenai pengaruh indeks economic policy uncertainty negara maju yang di dalamnya terdapat negara Tiongkok secara signifikan memiliki dampak negatif terhadap IHSG. Tiongkok juga menjadi negara ekonomi terbesar kedua dan negara adidaya ekonomi yang kritis (Zhang et al.,2018).

$\mathrm{H}_{2}$ : Ketidakpastian Kebijakan Ekonomi Tiongkok Berpengaruh Negatif terhadap Jakarta Islamic Index

\subsubsection{Pengaruh Negatif Ketidakpastian Kebijakan Ekonomi Jepang terhadap Jakarta Islamic Index}

Perubahan yang terjadi dalam indeks EPU Jepang adalah biasa dan relatif kecil. Hal ini terjadi karena pemerintah terus menerapkan ekspansi pada kebijakan fiskal, moneter, dan valuta asing, sehingga dampak EPU Jepang hanya mempengaruhi risiko penularan di pasar negara berkembang (Tsai, 2017). Dampak dari ketidakpastian

Maulidia Royhana dan Titi Dewi Warninda (Pengaruh Ketidakpastian Kebijakan Ekonomi 
kebijakan ekonomi Jepang yang tinggi pada akhirnya membawa dampak negatif pada JII.

$\mathrm{H}_{3}$ : Ketidakpastian Kebijakan Ekonomi Jepang Berpengaruh Negatif terhadap Jakarta Islamic Index

\subsubsection{Pengaruh Positif Harga Emas Dunia terhadap Jakarta Islamic Index}

Sunariyah (2006) menyatakan bahwa emas merupakan salah satu bentuk investasi yang cenderung bebas resiko. Ketika akan berinvestasi, investor akan memilih investasi yang memiliki timbal balik tinggi dengan resiko yang rendah. Investasi di pasar saham tentunya lebih berisiko daripada berinvestasi di pasar emas. Secara umum permintaan emas dapat dibagi menjadi dua yaitu pertama, permintaan penggunaan, dimana emas digunakan secara langsung dalam proses produksi perhiasan, medali, koin, komponen listrik, dan sebagainya. Kedua, permintaan asset, dimana emas digunakan oleh pemerintah, fund manager, dan sebagai investasi individu.

Emas juga merupakan bentuk investasi yang sangat liquid, karena dapat diterima di wilayah atau di negara mana pun. Ketika potensi imbalan (return) berinvestasi dalam saham atau obligasi tidak lagi menarik dan dianggap tidak mampu mengompensasi risiko yang ada, maka investor akan mengalihkan dananya ke dalam aset rill seperti logam mulia atau properti yang dianggap lebih layak dan aman. Harga emas dunia berpengaruh positif terhadap JII (Agestiani dan Sutanto, 2019).

\section{$\mathrm{H}_{4}$ : Harga Emas Dunia Berpengaruh Positif terhadap Jakarta Islamic Index}

\subsubsection{Pengaruh Positif Harga Minyak Dunia terhadap Jakarta Islamic Index}

Minyak merupakan salah satu komoditi yang cukup penting bagi perekonomian Indonesia. Harga minyak dunia memiliki pengaruh terhadap pasar modal. Bagi negara pengekspor minyak dan perusahaan sektor pertambangan, kenaikan harga minyak dunia dapat memberi keuntungan karena akan menarik minat investor (Munawaroh dan Handayani, 2019). Kebutuhan minyak mentah yang semakin meningkat seiring dengan munculnya negaranegara industri baru secara langsung akan mempengaruhi harga minyak mentah dunia. Hal tersebut jika dikaitkan dengan aktivitas perekonomian maka harga minyak akan berpengaruh terhadap perekonomian suatu negara. Bagi negara penghasil minyak (pengekspor), kenaikan harga minyak menggambarkan adanya pemindahan kesejahteraan dari negara pengimpor minyak ke negara pengekspor minyak. Hal ini akan berdampak pada penerimaan dan kesejahteraan masyarakatnya (Raraga et al.,2012).

$\mathrm{H}_{5}$ : Harga Minyak Dunia Berpengaruh Positif terhadap Jakarta Islamic Index 


\subsection{Model Penelitian}

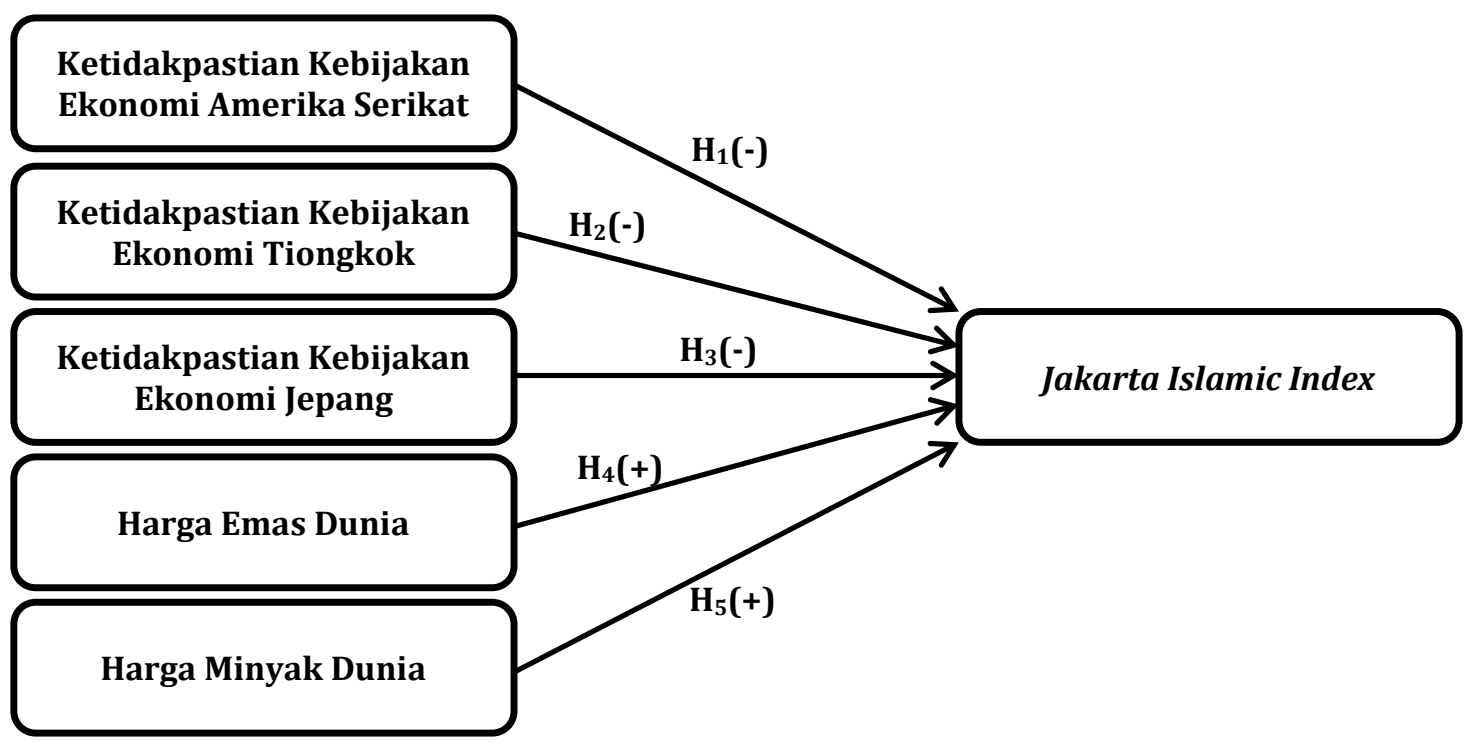

Gambar 6. Model Penelitian

\section{Metode Penelitian}

Ruang lingkup penelitian ini adalah menganalisis ketidakpastian kebijakan ekonomi Amerika Serikat, Tiongkok, dan Jepang terhadap JII dengan menggunakan variabel kontrol yaitu Harga Emas Dunia dan Harga Minyak Dunia. Penelitian ini merupakan penelitian kuantitatif dan menggunakan data runtut waktu (time series). Adapun periode penelitian adalah bulan Januari 2001 sampai dengan Desember 2019.

Teknik analisis yang digunakan adalah Error Correction Model (ECM). Penggunaan ECM adalah untuk menganalisis pengaruh jangka pendek dan jangka panjang ketidakpastian kebijakan ekonomi Amerika Serikat, Tiongkok, dan Jepang terhadap JII. ECM adalah model dinamis untuk mengoreksi ketidakseimbangan data deret waktu jangka pendek ke dalam ekuilibrium jangka panjang. Kelebihannya dalam menggabungkan efek jangka pendek dan jangka panjang, ECM menjadi model yang dapat menjelaskan variabel penjelas dengan baik (Warninda, 2013).

Pengujian yang dilakukan dalam ECM adalah:

1) Uji Stasioneritas

Uji stasioneritas adalah untuk menentukan stasioneritas data menggunakan uji akar unit Dickey-Fuller $(D F)$. Prosedur untuk menentukan apakah data stasioner atau tidak dengan cara membandingkan antara nilai statistic $D F$ dengan nilai kritisnya yaitu distribusi statistic $T$. Jika nilai absolut statistic $D F$ lebih besar dari nilai kritisnya, maka menolak hipotesis nol sehingga data yang diamati menunjukkan stasioner.

2) Uji Derajat Integrasi

Jika uji stasioneritas menghasilkan kesimpulan bahwa data tidak stasioner, maka diperlukan langkah untuk membuat data menjadi stasioner melalui proses diferensi data. Uji stasioner data melalui proses diferensi ini disebut uji derajat integrasi.

3) Uji kointegrasi

Uji kointegrasi adalah untuk mengetahui apakah terdapat hubungan jangka panjang yang terjadi antar variabel. Uji kointegrasi yang digunakan adalah uji kointegrasi Johansen.

Uji Asumsi klasik yang digunakan dalam penelitian ini yaitu uji normalitas menggunakan uji Jarque-Bera (J-B), uji multikolinearitas menggunakan uji Variance Inflation Factor, uji Autokorelasi menggunakan uji Breusch-Godfrey Serial Correlation LM, dan uji heteroskedastisitas menggunakan uji heteroskedastisitas $A R C H$. 
Persamaan yang digunakan dalam penelitian ini adalah sebagai berikut:

dimana:

$$
D Y_{t}=b_{0}+b_{1} D X_{1 t}+b_{2} D X_{2 t}+b_{3} D X_{3 t}+b_{4} D X_{4 t}+b_{5} D X_{5 t}+b_{6} E C T_{t-1}+e_{t}
$$

$\mathrm{Y}=$ Logaritma Natural Jakarta Islamic Index (JII)

$\mathrm{X}_{1}=$ Logaritma Natural Ketidakpastian Kebijakan Ekonomi Amerika Serikat (United State EPU)

$\mathrm{X}_{2}=$ Logaritma Natural Ketidakpastian Kebijakan Ekonomi Tiongkok (Tiongkok EPU)

$\mathrm{X}_{3}=$ Logaritma Natural Ketidakpastian Kebijakan Ekonomi Jepang (Japan EPU)

$\mathrm{X}_{4}=$ Logaritma Natural Harga Emas Dunia (HED)

$\mathrm{X}_{5}=$ Logaritma Natural Harga Minyak Dunia (HMD)

$\mathrm{ECT}=$ Error Correction Term

$e=$ Variabel Pengganggu

4. Hasil dan Pembahasan

\subsection{Hasil Uji Asumsi Klasik}

4.1.1. Uji Normalitas

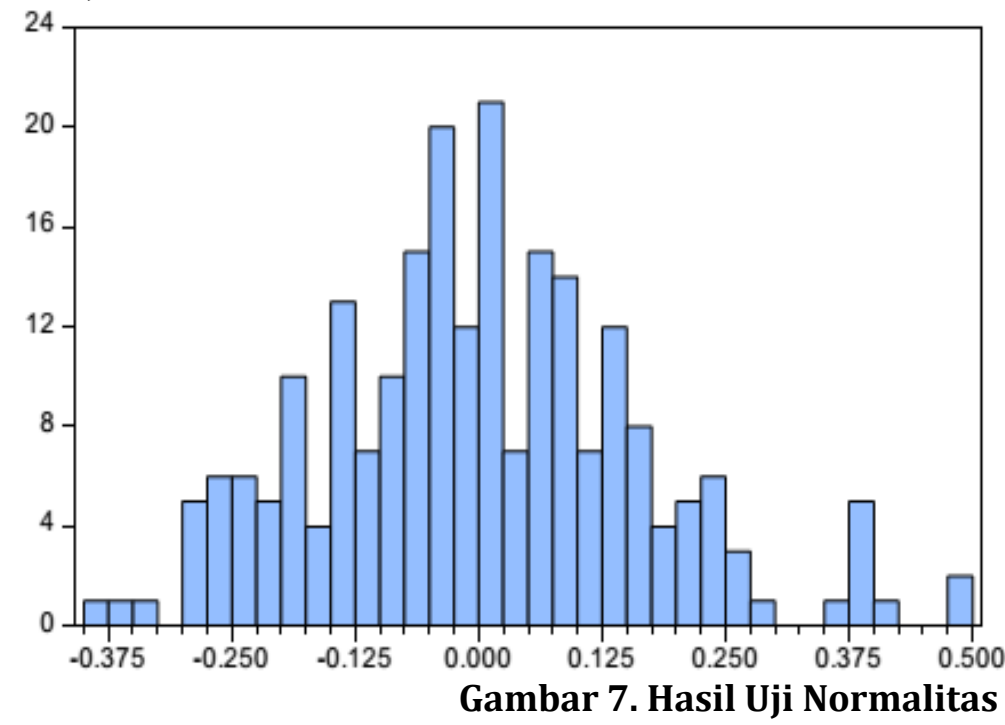

Series: Residuals

Sample 2001M01 2019M12

Observations 228

Mean

$-2.67 e-15$

Median $-0.003368$

Maximum

0.485355

Minimum $\quad-0.377952$

Std. Dev. $\quad 0.162490$

Skewness $\quad 0.312550$

Kurtosis $\quad 3.156095$

Jarque-Bera $\quad 3.943596$

Probability

Gambar 7 menunjukkan nilai probability sebesar 0,139206 atau lebih besar dari taraf signifikansi $5 \%(0,05)$ sehingga dapat disimpulkan bahwa residual terdistribusi normal.

\subsubsection{Uji Multikolinearitas}

Tabel 1. Hasil Uji Multikolinearitas

\begin{tabular}{cccc}
\hline Variable & Coefficient Variance & Uncentered VIF & Centered VIF \\
\hline LN United State & 0,002783 & 524,6833 & 2,127685 \\
EPU & & & \\
LN TIONGKOK EPU & 0,000389 & 83,86396 & 1,984212 \\
LN JAPAN EPU & 0,002813 & 510,6064 & 2,063574 \\
LN HED & 0,001474 & 568,4992 & 4,203925 \\
LN HMD & 0,001902 & 268,6547 & 3,163110 \\
\hline
\end{tabular}

Tabel 1 menunjukkan bahwa semua nilai VIF kurang dari 10. Dengan demikian dapat disimpulkan bahwa dalam penelitian ini tidak terdapat multikolinieritas. 


\subsubsection{Uji Heteroskedastisitas}

Tabel 2. Hasil Uji Heteroskedastisitas

\begin{tabular}{lrll}
\hline Heteroskedasticity Test: (ARCH) & & \\
\hline F-Statistic & 0,019478 & Prob. F(1,224) & 0,8891 \\
Obs*R-Squared & 0,019650 & Prob. Chi-Square(1) & 0,8885 \\
\hline
\end{tabular}

Tabel 2 menjelaskan hasil dari pengujian heteroskedastisitas diperoleh bahwa nilai $O b s^{*} R$-Squared adalah sebesar 0,019650 dengan nilai prob. sebesar 0,8885 atau lebih besar dari $5 \%(0,05)$. Dengan demikian, dapat diartikan bahwa pada penelitian ini tidak terdapat heteroskedastisitas.

\subsubsection{Uji Autokorelasi}

Tabel 3. Hasil Uji Autokorelasi

\begin{tabular}{llll}
\hline Breusch-Godfrey Serial Correlation LM Test: & \\
\hline F-Statistic & 2,647458 & Prob. F(2,213) & 0,0732 \\
& 5,506066 & Prob. Chi-Square(2) & 0,0637 \\
\hline
\end{tabular}

Tabel 3 menjelaskan hasil uji autokorelasi nilai probabilitas chi-square sebesar 0,0637 atau lebih besar dari 5\% $(0,05)$. Dengan demikian, dapat diartikan bahwa tidak terdapat autokorelasi.

\subsection{Hasil Uji Stasioneritas}

Tabel 4. Hasil Uji Stasioneritas pada Tingkat Level

\begin{tabular}{|c|c|c|c|c|c|c|}
\hline \multirow[t]{2}{*}{ Variabel } & \multirow{2}{*}{$\begin{array}{c}\text { ADF T- } \\
\text { Statistic }\end{array}$} & \multicolumn{3}{|c|}{ Nilai Kritis } & \multirow{2}{*}{ Prob } & \multirow[t]{2}{*}{ Keterangan } \\
\hline & & $1 \%$ & $5 \%$ & $10 \%$ & & \\
\hline JII & $-1,789$ & $-3,459$ & $-2,874$ & $-2,573$ & 0,385 & $\begin{array}{c}\text { Tidak } \\
\text { Stasioner }\end{array}$ \\
\hline $\begin{array}{c}\text { United } \\
\text { State EPU }\end{array}$ & $-2,217$ & $-3,459$ & $-2,874$ & $-2,573$ & 0,201 & $\begin{array}{c}\text { Tidak } \\
\text { Stasioner }\end{array}$ \\
\hline $\begin{array}{c}\text { TIONGKOK } \\
\text { EPU }\end{array}$ & $-1,721$ & $-3,459$ & $-2,874$ & $-2,573$ & 0,419 & $\begin{array}{c}\text { Tidak } \\
\text { Stasioner }\end{array}$ \\
\hline JAPAN EPU & $-5,213$ & $-3,459$ & $-2,874$ & $-2,573$ & 0,000 & Stasioner \\
\hline HED & $-2,038$ & $-3,459$ & $-2,874$ & $-2,573$ & 0,270 & $\begin{array}{c}\text { Tidak } \\
\text { Stasioner }\end{array}$ \\
\hline HMD & $-2,336$ & $-3,459$ & $-2,874$ & $-2,573$ & 0,162 & $\begin{array}{c}\text { Tidak } \\
\text { Stasioner }\end{array}$ \\
\hline
\end{tabular}

Berdasarkan tabel 4 menunjukkan bahwa pada tingkat level Jakarta Islamic Index, United State EPU, Tiongkok EPU, Harga Emas Dunia, dan Harga Minyak Dunia tidak stasioner dapat dilihat dari nilai Augmented Dickey-Fuller (ADF) $t$-statistic yang lebih kecil dari nilai kritikal MacKinnon dengan nilai probabilitas JII sebesar 0,3853, US EPU sebesar 0,2009, Tiongkok EPU sebesar 0,4194, Harga Emas Dunia sebesar 0,2703 dan Harga Minyak Dunia sebesar 0,1616 yang menunjukkan lebih besar dari nilai 5\% $(0,05)$, sedangkan Japan EPU stasioner dengan nilai Augmented Dickey-Fuller (ADF) t-statistic yang lebih kecil dari nilai kritikal MacKinnon dengan nilai probabilitas 0,0000 menunjukkan lebih kecil dari nilai 5\% $(0,05)$.

Dengan demikian, dapat disimpulkan bahwa terdapat lima variabel yang tidak stasioner pada tingkat level yaitu Jakarta Islamic Index, United State EPU, Tiongkok EPU, Harga Emas Dunia, dan Harga Minyak Dunia. Sementara variabel Japan EPU pada tingkat level sudah stasioner. Apabila data yang digunakan dalam model ada yang tidak stasioner, maka data tersebut harus dipertimbangkan kembali validitasnya, karena hasil regresi yang berasal dari data yang tidak stasioner akan menyebabkan spurious regression. Langkah

Maulidia Royhana dan Titi Dewi Warninda (Pengaruh Ketidakpastian Kebijakan Ekonomi 
selanjutnya yang perlu dilakukan adalah uji derajat integrasi untuk mengetahui pada derajat ke berapa variabel-variabel tersebut stasioner (Gujarati, 2003).

\subsection{Hasil Uji Derajat Integrasi}

Tabel 5. Hasil Uji Derajat Integrasi pada Tingkat First Difference

\begin{tabular}{|c|c|c|c|c|c|c|}
\hline \multirow[t]{2}{*}{ Variabel } & \multirow{2}{*}{$\begin{array}{c}\text { ADF T- } \\
\text { Statistic }\end{array}$} & \multicolumn{3}{|c|}{ Nilai Kritis } & \multirow[t]{2}{*}{ Prob } & \multirow[t]{2}{*}{ Keterangan } \\
\hline & & $1 \%$ & $5 \%$ & $10 \%$ & & \\
\hline JII & $-12,167$ & $-3,459$ & $-2,874$ & $-2,573$ & 0,000 & Stasioner \\
\hline United & $-11,526$ & $-3,459$ & $-2,874$ & $-2,573$ & 0,000 & Stasioner \\
\hline State EPU & & & & & & \\
\hline $\begin{array}{c}\text { TIONGKOK } \\
\text { EPU }\end{array}$ & $-18,629$ & $-3,459$ & $-2,874$ & $-2,573$ & 0,000 & Stasioner \\
\hline JAPAN EPU & $-13,160$ & $-3,459$ & $-2,874$ & $-2,573$ & 0,000 & Stasioner \\
\hline HED & $-13,074$ & $-3,459$ & $-2,874$ & $-2,573$ & 0,000 & Stasioner \\
\hline HMD & $-12,011$ & $-3,459$ & $-2,874$ & $-2,573$ & 0,000 & Stasioner \\
\hline
\end{tabular}

Berdasarkan tabel 5 menunjukkan bahwa semua variabel pada tingkat first difference sudah bersifat stasioner. Dapat dilihat dari nilai Augmented Dickey-Fuller (ADF) t-statistic yang lebih besar dari nilai kritikal MacKinnon dengan nilai probabilitas sebesar 0,0000 yang menunjukkan lebih kecil dari nilai $5 \%(0,05)$.

\subsection{Hasil Uji Kointegrasi}

Tabel 6. Hasil Uji Kointegrasi

\begin{tabular}{ccccc}
\hline $\begin{array}{c}\text { Unrestricted Cointegration Rank Test (Trace) } \\
\text { Hypothesized } \\
\text { No. Of CE(s) }\end{array}$ & Eigenvalue & Trace Statistic & $\begin{array}{c}\text { 0,05 } \\
\text { Critical Value }\end{array}$ & Prob.** \\
\hline None * & 0,677441 & 829,9426 & 95,75366 & 0,0001 \\
At most 1 * & 0,522325 & 575,3619 & 69,81889 & 0,0001 \\
At most 2 * & 0,466222 & 409,1262 & 47,85613 & 0,0001 \\
At most 3 & 0,389801 & 267,8767 & 29,79707 & 0,0001 \\
At most 4 & 0,324539 & 156,7334 & 15,49471 & 0,0001 \\
At most 5 * & 0,262311 & 68,45234 & 3,841466 & 0,0000 \\
\hline
\end{tabular}

Berdasarkan tabel 6 di atas, menunjukkan bahwa nilai trace statistic dari variabel United State EPU menunjukkan lebih besar dari critical value pada taraf nyata $5 \%$ yaitu 575,3619 > 69,81889 dan nilai Max-Eigen Statistic yang lebih besar dari nilai critical value pada taraf nyata $5 \%$ yaitu $166,2357>33,87687$. Hal ini menunjukkan bahwa United State EPU memiliki hubungan keseimbangan jangka panjang (kointegrasi) dengan JII. Dengan demikian, analisis selanjutnya akan menggunakan model Error Correction Model (ECM).

Berdasarkan tabel 6 di atas, menunjukkan bahwa nilai trace statistic dari variabel Tiongkok EPU menunjukkan lebih besar dari critical value pada taraf nyata 5\% yaitu 409,1262 > 47,85613 dan nilai Max-Eigen Statistic yang lebih besar dari nilai critical value pada taraf nyata $5 \%$ yaitu $141,2495>27,58434$. Hal ini menunjukkan bahwa Tiongkok EPU memiliki hubungan keseimbangan jangka panjang (kointegrasi) dengan JII. Dengan demikian, analisis selanjutnya akan menggunakan model Error Correction Model (ECM).

Berdasarkan tabel 6 di atas, menunjukkan bahwa nilai trace statistic dari variabel Japan EPU menunjukkan lebih besar dari critical value pada taraf nyata 5\% yaitu 267,8767 $>$ 29,79707 dan nilai Max-Eigen Statistic yang lebih besar dari nilai critical value pada taraf nyata 5\% yaitu 111,1433 > 21,13162. Hal ini menunjukkan bahwa Japan EPU memiliki hubungan keseimbangan jangka panjang (kointegrasi) dengan JII. Dengan demikian, analisis selanjutnya akan menggunakan model Error Correction Model (ECM). 
Berdasarkan tabel 6 di atas, menunjukkan bahwa nilai trace statistic dari variabel HED menunjukkan lebih besar dari critical value pada taraf nyata 5\% yaitu 165,7334 $>$ 15,49471 dan nilai Max-Eigen Statistic yang lebih besar dari nilai critical value pada taraf nyata 5\% yaitu 88,28104 > 14,26460. Hal ini menunjukkan bahwa HED memiliki hubungan keseimbangan jangka panjang (kointegrasi) dengan JII. Dengan demikian, analisis selanjutnya akan menggunakan model Error Correction Model (ECM).

Berdasarkan tabel 6 di atas, menunjukkan bahwa nilai trace statisticdan nilai MaxEigen Statistic dari variabel HMD menunjukkan lebih besar dari critical value pada taraf nyata $5 \%$ yaitu $68,45234>3,841466$. Hal ini menunjukkan bahwa HMD memiliki hubungan keseimbangan jangka panjang (kointegrasi) dengan JII. Dengan demikian, analisis selanjutnya akan menggunakan model Error Correction Model (ECM).

Adanya kointegrasi pada semua variabel tersebut berarti ada hubungan atau keseimbangan jangka panjang antara variabel penelitian. Dalam jangka pendek mungkin saja ada ketidakseimbangan (disequilibrium). Ketidakseimbangan inilah yang sering ditemui dalam perilaku ekonomi, sehingga langkah selanjutnya untuk melakukan koreksi bagi ketidakseimbangan disebut sebagai model koreksi kesalahan atau Error Correction Model (ECM) (Widarjono, 2018).

\subsection{Hasil Estimasi Error Correction Model (ECM)}

Tabel 7. Hasil Estimasi ECM

\begin{tabular}{ccccc}
\hline Variable & Coefficient & Std. Error & T-Statistic & Prob. \\
\hline $\begin{array}{c}\text { D(LN United } \\
\text { State EPU) }\end{array}$ & -0.047961 & 0.026077 & -1.839208 & 0.0673 \\
D(LN TIONGKOK & & & & \\
EPU) & -0.005702 & 0.009219 & -0.618525 & 0.5369 \\
D(LN JAPAN & & & & \\
EPU) & -0.084413 & 0.024607 & -3.430437 & 0.0007 \\
D(LN HED) & 0.315831 & 0.111961 & 2.820900 & 0.0052 \\
D(LN HMD) & 0.108794 & 0.047044 & 2.312601 & 0.0217 \\
LN United State & & & & \\
EPU(-1) & 0.016852 & 0.022411 & 0.751946 & 0.4529 \\
LN TIONGKOK & & & & \\
EPU(-1) & -0.015955 & 0.008169 & -1.953176 & 0.0521 \\
LN JAPAN EPU(- & & & & \\
1) & -0.036585 & 0.022484 & -1.627123 & 0.1052 \\
LN HED(-1) & 0.025852 & 0.015041 & 1.718830 & 0.0871 \\
LN HMD(-1) & -0.039877 & 0.016866 & -2.364337 & 0.0190 \\
ECT & 0.062221 & 0.027482 & 2.264040 & 0.0246 \\
C & 0.165438 & 0.078785 & 2.099867 & 0.0369 \\
\hline
\end{tabular}

Berdasarkan tabel 7 menunjukkan bahwa hasil estimasi ECM telah memenuhi kriteria sebagai model estimasi ECM berdasarkan koefisien regresi Error Correction Term (ECT) sebesar 0,062221 dengan nilai probabilitas sebesar 0,0246 yang berarti signifikan pada taraf nyata $5 \%$ atau kurang dari 0,05 . Dengan demikian, spesifikasi model yang digunakan dalam penelitian ini adalah tepat dan mampu menjelaskan hubungan jangka pendek maupun jangka panjang, sehingga dapat diartikan bahwa model ECT valid untuk digunakan.

Variabel jangka pendek dari estimasi model tersebut dapat dilihat pada D(LN United State EPU), D(LN TIONGKOK EPU), D(LN JAPAN EPU), D(LN HED), dan D(LN HMD). Kemudian untuk persamaan variabel jangka panjangnya dapat dilihat pada LN United State EPU(-1), LN TIONGKOK EPU(-1), LN JAPAN EPU(-1), LN HED(-1), dan LN HMD(-1).

Maulidia Royhana dan Titi Dewi Warninda (Pengaruh Ketidakpastian Kebijakan Ekonomi 


\subsection{Pembahasan}

\subsubsection{Ketidakpastian Kebijakan Ekonomi Amerika Serikat (United State EPU)} Berpengaruh Negatif terhadap Jakarta Islamic Index

Berdasarkan tabel 7 di atas, menunjukkan bahwa nilai probabilitas United State EPU dalam jangka pendek adalah sebesar 0,0673 dan dalam jangka panjang nilai probabilitas United State EPU adalah sebesar 0,4529 atau lebih besar dari taraf signifikansi 5\% sehingga secara signifikan United State EPU tidak berpengaruh negatif terhadap JII baik jangka pendek maupun jangka panjang. Dengan demikian, hipotesis pertama yang menjelaskan bahwa ketidakpastian kebijakan ekonomi Amerika Serikat (United State EPU) berpengaruh negatif terhadap JII ditolak. Dari penjelasan di atas dapat dijelaskan bahwa variabel United State EPU tidak berpengaruh negatif signifikan baik dalam jangka pendek maupun jangka panjang terhadap JII.

Hasil ini sesuai dengan penelitian Li dan Zhong (2020) yang menyatakan bahwa efek limpahan EPU global yang di dalamnya terdapat US EPU pada Indeks Kondisi Keuangan China (CFCI) terkonsentrasi pada periode krisis, tetapi sebagian besar efek tidak signifikan pada periode normal. Namun hasil ini tidak sesuai dengan penelitian Gilal (2019) menghasilkan bahwa terdapat hubungan ekonomi antarvariabel yang konsisten antara US EPU dan IHSG serta Ariputra (2017) mengenai pengaruh indeks economic policy uncertainty negara maju yang di dalamnya terdapat negara Amerika Serikat yang memiliki dampak positif atau berpengaruh secara signifikan terhadap IHSG.

\subsubsection{Ketidakpastian Kebijakan Ekonomi Tiongkok (Tiongkok EPU) Berpengaruh Negatif terhadap Jakarta Islamic Index}

Berdasarkan tabel 7 di atas menunjukkan bahwa nilai probabilitas Tiongkok EPU dalam jangka pendek adalah sebesar 0,5369 dan dalam jangka panjang sebesar 0,0521 atau lebih besar dari taraf signifikansi 5\% sehingga secara signifikan Tiongkok EPU tidak berpengaruh terhadap JII baik jangka pendek maupun jangka panjang. Dengan demikian, hipotesis kedua yang menjelaskan bahwa ketidakpastian kebijakan ekonomi Tiongkok (Tiongkok EPU) berpengaruh negatif terhadap JII ditolak. Dari penjelasan di atas dapat dijelaskan bahwa variabel Tiongkok EPU tidak berpengaruh negatif signifikan baik dalam jangka pendek maupun jangka panjang terhadap JII.

Hasil ini sesuai dengan penelitian Li dan Zhong (2020) yang menyatakan bahwa efek limpahan EPU global yang di dalamnya terdapat Tiongkok EPU pada Indeks Kondisi Keuangan China (CFCI) terkonsentrasi pada periode krisis, tetapi sebagian besar efek tidak signifikan pada periode normal. Namun hasil ini tidak sesuai dengan penelitian Ariputra (2017) mengenai pengaruh indeks economic policy uncertainty negara maju yang didalamnya terdapat negara Tiongkok memiliki dampak negatif terhadap IHSG.

\subsubsection{Ketidakpastian Kebijakan Ekonomi Jepang (Japan EPU) Berpengaruh Negatif terhadap Jakarta Islamic Index}

Berdasarkan tabel 7 di atas menunjukkan bahwa nilai probabilitas Japan EPU dalam jangka pendek adalah sebesar 0,0007 atau lebih kecil dari taraf signifikansi 5\% sehingga secara signifikan Japan EPU berpengaruh negatif terhadap JII. Dalam jangka panjang nilai probabilitas Japan EPU adalah sebesar 0,1052 atau lebih besar dari taraf signifikansi 5\% sehingga secara signifikan Japan EPU tidak berpengaruh terhadap JII. Dengan demikian, hipotesis ketiga yang menjelaskan bahwa ketidakpastian kebijakan ekonomi Jepang (Japan EPU) berpengaruh negatif terhadap JII ditolak. Dari penjelasan di atas dapat dijelaskan bahwa Jepang EPU tidak berpengaruh negatif signifikan baik dalam jangka pendek maupun jangka panjang terhadap JII. 
Hasil ini sesuai dengan penelitian Ariputra (2017) mengenai pengaruh indeks economic policy uncertainty negara maju yang didalamnya terdapat negara Jepang berpengaruh terhadap IHSG dan penelitian yang dilakukan oleh Tsai (2017) yang menyatakan bahwa dampak EPU Jepang hanya mempengaruhi risiko penularan di pasar negara berkembang.

\subsubsection{Harga Emas Dunia Berpengaruh Positif terhadap Jakarta Islamic Index}

Berdasarkan tabel 7 di atas, menunjukkan bahwa nilai probabilitas HED dalam jangka pendek adalah sebesar 0,0052 atau lebih kecil dari taraf signifikansi 5\% dan dalam jangka panjang nilai probabilitasnya adalah sebesar 0,0871 atau lebih besar dari taraf signifikansi 5\%. Dengan demikian, variabel HED secara positif berpengaruh dalam jangka pendek namun dalam jangka panjang tidak berpengaruh secara positif terhadap JII. Hipotesis keempat yang mengatakan harga emas dunia berpengaruh positif terhadap JII ditolak.

Hasil penelitian ini sesuai dengan penelitian yang dilakukan oleh Robiyanto (2018), Harif et al., (2018), Agestiani dan Sutanto (2019), Salihin (2019) menyatakan bahwa variabel HED berpengaruh positif terhadap JII. Hal ini berarti investor menjadikan emas sebagai investasinya melihat dari harga emas yang tidak mudah berubah-ubah atau stabil dan relatif mengalami peningkatan terus-menerus sehingga dapat menghindari risiko dalam berinvestasi dan harga emas dapat mengalami penurunan yang terjadi akibat adanya penurunan pada perekonomian, maka investor akan mengalihkan investasinya dari pasar modal ke luar sektor yang salah satunya adalah pada emas, sehingga dengan hal ini indeks saham syariah juga akan mengalami penurunan. Namun hasil penelitian ini tidak sesuai dengan penelitian Nellawati dan Isbanah (2019) bahwa harga emas dunia tidak berpengaruh pada IHSG karena tujuan rakyat dalam membeli emas lebih bersifat untuk perhiasan dan bukan untuk tujuan investasi.

\subsubsection{Harga Minyak Dunia Berpengaruh Positif terhadap Jakarta Islamic Index}

Berdasarkan tabel 7 di atas, menunjukkan bahwa nilai probabilitas HMD dalam jangka pendek adalah sebesar 0,0217 dan dalam jangka panjang nilai probabilitasnya adalah sebesar 0,0190 atau lebih kecil dari taraf signifikansi 5\%. Dengan demikian, variabel HMD secara positif berpengaruh dalam jangka pendek namun dalam jangka panjang tidak berpengaruh secara positif terhadap JII. Hipotesis kelima yang mengatakan harga minyak dunia berpengaruh positif terhadap JII ditolak.

Hasil ini sesuai dengan peneliti Wang dan Chueh (2013) menyatakan bahwa HMD dan HED saling mempengaruhi satu sama lain dan HMD juga berpengaruh positif terhadap suku bunga. Penelitian yang dilakukan oleh Harif et al., (2018), Munawaroh dan Handayani (2019) menjelaskan bahwa HMD memiliki pengaruh positif terhadap indeks harga saham gabungan. Hal ini berarti pada saat HMD turun, maka indeks harga saham gabungan di BEI turun, begitu pula sebaliknya pada saat HMD naik, maka indeks harga saham di BEI juga naik. Hasil penelitian menunjukkan bahwa HMD merupakan salah satu faktor penentu yang menjelaskan keragaman atas perubahan indeks harga saham gabungan di BEI. Namun hasil ini tidak sesuai dengan penelitian dari Widad dan Hadjer (2018) harga minyak di berbagai tingkat dan arah, memiliki respons yang lemah atau tidak signifikan antara logam mulia itu sendiri. Penelitian dari Istamar et al., (2019) menjelaskan bahwa variabel harga minyak dunia tidak berpengaruh secara signifikan terhadap indeks harga saham gabungan. Hal ini berarti ketika keadaan geopolitik tidak stabil yang juga memicu harga minyak sering mengalami lonjakan tinggi dan mengalami penurunan drastis yang sering terjadi, momen geopolitik dan fluktuasi ini mengakibatkan pada perubahan kinerja seluruh korporasi dunia. Selain itu, 
investor juga akan beralih berinvestasi ke sektor lainnya yang cenderung aman dan bebas dari risiko.

\section{Kesimpulan dan Saran}

\subsection{Kesimpulan}

Berdasarkan hasil penelitian yang sudah dilakukan, maka diperoleh kesimpulan sebagai berikut:

1. Variabel ketidakpastian kebijakan ekonomi yang berpengaruh negatif dalam jangka pendek terhadap JII adalah Japan EPU. Kemudian variabel yang tidak berpengaruh negatif dalam jangka pendek adalah United State EPU dan Tiongkok EPU. Sedangkan dalam jangka panjang variabel United State EPU, Tiongkok EPU, dan Japan EPU tidak berpengaruh negatif terhadap JII.

2. Variabel kontrol yang berpengaruh positif dalam jangka pendek terhadap JII adalah HED dan HMD. Kemudian variabel yang berpengaruh signifikan dalam jangka panjang adalah HMD tetapi dengan pengaruh negatif. Sedangkan variabel kontrol HED tidak berpengaruh signifikan dalam jangka panjang terhadap JII.

\subsection{Saran}

Berdasarkan penelitian yang sudah dilakukan, maka saran yang dapat diberikan sebagai berikut:

1. Hasil penelitian menunjukkan bahwa secara umum ketidakpastian kebijakan ekonomi negara Amerika Serikat, Tiongkok, dan Jepang kurang berpengaruh signifikan terhadap pasar modal syariah di Indonesia. Diperlukan penelitian lebih lanjut mengenai pengaruh ketidakpastian kebijakan ekonomi dari negara-negara lain terhadap pasar modal syariah di Indonesia.

2. Penelitian berikutnya menggunakan indeks penelitian dari negara lain selain yang digunakan dalam penelitian ini.

\section{Daftar Pustaka}

Agestiani, A., \& Sutanto, H.A. (2019). Pengaruh Indikator Makro Dan Harga Emas Dunia terhadap Indeks Harga Saham Syariah (Jakarta Islamic Index). Journal of Economics and Banking, 1(1), 26-38.

Alqahtani, A., \& Martinez, M. (2020). US Economic Policy Uncertainty and GCC Stock Market. AsiaPacific Financial Markets, 27(3), 415-425.

Anshari, A.G. (2008). Penerapan Prinsip Syariah Dalam Lembaga Keuangan, Lembaga Pembiayaan, dan Perusahaan Pembiayaan. Pustaka Pelajar.

Ariputra, Yohanes Aditya. (2017). Pengaruh Indeks Economic Policy Uncertainty Negara Maju Terhadap Pasar Saham Indonesia Tahun 1998-2016. (Tesis Tidak Dipublikasikan). Universitas Sebelas Maret, Surakarta.

Baker, S., Bloom, N., \& Davis, S. (2016). Measuring Economic Policy Uncertainty. Quarterly Journal of Economics, 131(4), 1593-1636.

Beik, I.S., \& Fatmawati, S.W. (2014). Pengaruh Indeks Harga Saham Syariah Internasional dan Variabel Makro Ekonomi terhadap Jakarta Islamic Index. Jurnal Ilmu Ekonomi Syariah Al Iqtishad, 6(2), 155-178. 
Davis, S. J. (2019). Rising Policy Uncertainty (No. w26243). National Bureau of Economic Research.

Faniyah, I. (2017). Investasi Syariah dalam Pembangunan Ekonomi Indonesia. Deepublish Publisher.

Gilal, M. (2019). Economic Policy Uncertainty and Stock Market Returns in Indonesia. Associate Professor Departemen Ekonomi, Uniersity of Sindh Jamshoro.

Gujarati, D. (2003). Ekonometri Dasar. Terjemahan: Sumarno Zain. Erlangga.

Harif, L.H., Harafah, L.O.M. \& Natsir, M. (2018). The Effect Of Macroeconomic Variables On Indonesia Sharia Stock Index. Jurnal Progres Ekonomi Pembangunan (JPEP), 3(1).

Istamar, S., Sudati.N., \& Rusmijati. (2019). Analysis of The Influence of World Oil Prices, and Rupiah Exchange Rate of The Joint Stock Price Index In Indonesia Stock Exchange in 19982018. Directory Journal of Economic.

Li, Z., \& Zhong, J. (2020). Impact of Economic Policy Uncertainty Shocks on China's Financial Conditions. Finance Research Letters, 35, 1544-6123.

Mei, D., Zeng, Q., Zhang, Y., \& Hou, W. (2018). Does US Economic Policy Uncertainty Matter for European Stock Markets Volatility?. Physica A: Statistical Mechanics and its Applications, $512,215-221$.

Munawaroh, H., \& Handayani, S.R. (2019). Pengaruh BI RATE, Kurs Rupiah, Tingkat Inflasi, Harga Minyak Dunia, Harga Emas Dunia terhadap Indeks Harga Saham Gabungan (IHSG). Jurnal Administrasi Bisnis (JAB), 72(1), 27-36.

Nellawati, S.O. \& Isbanah, Y. (2019). Analisis Pengaruh Faktor Internal dan Faktor Eksternal terhadap Pergerakan Indeks Harga Gabungan (IHSG) di Bursa Efek Indonesia. Jurnal Ilmu Manajemen, 7(1), 113-123.

Oktaviani, R.F. (2017). Index Harga Saham Islamic Internasional terhadap Jakarta Islamic Index. Jurnal Ekonomika dan Manajemen, 6(1), 1-15.

Raraga, F., Chabachib, M., \& Muharam, H. (2012). Analisis Pengaruh Harga Minyak dan Harga Emas terhadap Hubungan Timbal-Balik Kurs dan Indeks Harga Saham Gabungan (IHSG) Di Bursa Efek Indonesia (BEI) 2000-2013. Doctoral Dissertation: Diponegoro University.

Robiyanto, R. (2018). The Effect Of Gold Price Changes, Usd/Idr Exchange Rate Changes And Bank Indonesia (BI) Rate On Jakarta Composite Index (JCI)'S Return And Jakarta Islamic Index (JII)'S Return. Jurnal Manajemen dan Kewirausahaan, 20(1), 45-51.

Rodoni, A. (2009). Investasi Syariah. Lembaga Penelitian UIN Jakarta.

Rodoni, A., \& Hamid, A. (2008). Lembaga Keuangan Syariah. Zikrul Hakim.

Sakti, M.R.P., \& Harun MD.Y. (2013). Relationship between Islamic Stock Prices and Macroeconomic Variables: Evidence from Jakarta Stock Exchange Islamic Index. Global Review of Islamic Economics and Business, 1(1), 71-84.

Maulidia Royhana dan Titi Dewi Warninda (Pengaruh Ketidakpastian Kebijakan Ekonomi

Amerika Serikat, Tiongkok, dan Jepang terhadap Jakarta Islamic Index) 
Salihin, A. (2019). Pengaruh Dow Jones Islamic Market (DJIM), Kurs, dan Harga Emas Dunia Terhadap Jakarta Islamic Indeks (JII) Periode 2016-2018. Jurnal Istiqro: Jurnal Hukum Islam, Ekonomi dan Bisnis, 5(2), 114-126.

Soemitra, A. (2015). Bank Dan Lembaga Keuangan Syariah. Prenada Media Group.

Sunariyah. (2006). Pengetahuan Pasar Modal, Edisi 5. UPP AMP YKPN.

Suryomurti, W. (2011). Super Cerdas Investasi Syariah. PT. Agro Media Pratama.

Tsai, I.C. (2017). The Source of Global Stock Market Risk: A Viewpoint Of Economic Policy Uncertainty. Economic Modelling, 60, 122-131.

Umam, K. (2013). Pasar Modal Syariah dan Praktik Pasar Modal Syariah. Pustaka Setia.

Wang, Y. S., \& Chueh, Y. L. (2013). Dynamic Transmission Effects between The Interest Rate, The US Dollar, and Gold and Crude Oil Prices. Economic Modelling, 30, 792-798.

Warninda, T,D. (2013). Dynamic Model of Islamic Bank Profitability. Journal of Islamic Banking \& Finance, 30(2), 87-122.

Widad, M., \& Hadjer, B. (2018). Causal Relationship Between Islamic Bonds, Oil Price, and Precious Metal: Evidence From Asia Pacific. Al-Iqtishad Journal of Islamic Economics, 10(2), 285-298.

Widarjono, A. (2018). EKONOMETRIKA: Pengantar dan Aplikasinya Disertai Panduan Eviews. UPPSTIM YKPN.

Zhang, D., Lei, L., Ji, Q., Kutan, A.M. (2018). Economic Policy Uncertainty In The US and China and Their Impact On The Global Markets. Economic Modelling, 79, 47-56. 